\title{
"Spatial tale of G-7 and BRICS stock markets during COVID-19: An event study"
}

\begin{tabular}{|c|c|}
\hline AUTHORS & $\begin{array}{l}\text { Sanket Ledwani (i) } \\
\text { Suman Chakraborty (i) } \\
\text { Sandeep S. Shenoy (D) }\end{array}$ \\
\hline ARTICLE INFO & $\begin{array}{l}\text { Sanket Ledwani, Suman Chakraborty and Sandeep S. Shenoy (2021). Spatial } \\
\text { tale of G-7 and BRICS stock markets during COVID-19: An event study. } \\
\text { Investment Management and Financial Innovations, 18(2), 20-36. } \\
\text { doi:10.21511/imfi.18(2).2021.03 }\end{array}$ \\
\hline DOI & http://dx.doi.org/10.21511/imfi.18(2).2021.03 \\
\hline RELEASED ON & Thursday, 15 April 2021 \\
\hline RECEIVED ON & Sunday, 15 March 2020 \\
\hline ACCEPTED ON & Wednesday, 07 April 2021 \\
\hline LICENSE & $\begin{array}{l}(c) \text { EY } \\
\text { This work is licensed under a Creative Commons Attribution } 4.0 \text { International } \\
\text { License }\end{array}$ \\
\hline JOURNAL & "Investment Management and Financial Innovations" \\
\hline ISSN PRINT & $1810-4967$ \\
\hline ISSN ONLINE & $1812-9358$ \\
\hline PUBLISHER & LLC "Consulting Publishing Company "Business Perspectives" \\
\hline FOUNDER & LLC "Consulting Publishing Company "Business Perspectives" \\
\hline
\end{tabular}

NUMBER OF REFERENCES

40

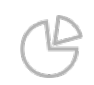

NUMBER OF FIGURES

7

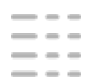

NUMBER OF TABLES

12

(C) The author(s) 2021. This publication is an open access article. 


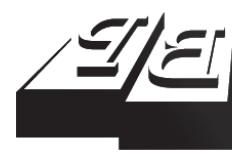

\section{BUSINESS PERSPECTIVES}

(O)

LLC "CPC "Business Perspectives" Hryhorii Skovoroda lane, 10, Sumy, 40022, Ukraine www.businessperspectives.org
Received on: $4^{\text {th }}$ of March, 2020 Accepted on: $7^{\text {th }}$ of April, 2021 Published on: $15^{\text {th }}$ of April, 2021

(c) Sanket Ledwani, Suman Chakraborty, Sandeep S. Shenoy, 2021

Sanket Ledwani, Doctoral Student, Department of Commerce, MIT Campus, Manipal Academy of Higher Education, Karnataka, India.

Suman Chakraborty, Dr., Associate Professor, Department of Commerce, MIT Campus, Manipal Academy of Higher Education, Karnataka, India. (Corresponding Author)

Sandeep S. Shenoy, Dr., Associate Professor, Head of the Department of Commerce, MIT Campus, Manipal Academy of Higher Education, Karnataka, India.

\section{SPATIAL TALE OF G-7 AND BRICS STOCK MARKETS DURING COVID-19: AN EVENT STUDY}

\begin{abstract}
The unprecedented outbreak of COVID-19 has affected every aspect of the human life, be it health, social, or economic dimensions. The anxiety and uncertainty wobbled the economies of affected countries worldwide. This study attempts to quantify the impact of COVID-19 on the performance of major stock markets of G-7 nations vis-à-vis BRICS nations. An event study methodology is employed to capture the effect of the systematic event in the form of Buy and Hold Abnormal Returns (BHAR) and Average Buy and Hold Abnormal Returns (ABHAR). The study considers a 90-day observation window, consisting of six sub-event windows after the COVID-19 news up-doves the world, and 120 days prior to the selected event date to estimate average expected returns. BHAR values in the four event windows are statistically significant, covering stock markets from panic and nosedive to their correction and recovery. ABHAR values reported are significantly negative in the event window ranging from $-0.15 \%$ to $-38.43 \%$ for G-7 and $-0.06 \%$ to $-37.12 \%$ for BRICS nations. Despite similar ABHAR trends, the BHAR values and correlation matrix exhibit a diverse reaction in BRICS nations compared to the highly synchronized reaction in the G-7 group of nations in the COVID period.
\end{abstract}

\section{Keywords abnormal returns, stock exchange, financial crisis,} pandemic, event study, volatility, BHAR

\section{JEL Classification G01, G11, G14, G15}

\section{INTRODUCTION}

The outbreak of the novel contagious coronavirus has a devastating impact on the health and financial prosperity of the human habitat across borders. Despite the Wuhan province of China witnessed the first blow of the COVID-19 outbreak in December 2019, it grabbed the attention of the world on January 20, 2020 when the outbreak was reported by the National Health and Fitness Commission (NHFC) of China. By March 11, 2020, the number of COVID-19 cases crossed the $1,18,000$ mark in 114 countries on the global map, which prompted the WHO to declare the event a global pandemic (Cucinotta \& Vanelli, 2020). Soon, all major stock markets nosedived, creating shivers in the nerves of global investors, and the event was claimed as the second-worst global economic crisis of the century after the recession of World War II (World bank, 2020).

COVID-19, being a global pandemic, is an event of its kind; no event with such intense impact and longitude has occurred in the recent past. The rapid global spread of the disease in March 2020 led the governments of affected countries to impose a complete lockdown and travel ban to contain the virus. These decisions have added to the panic and further slumped the economic activities concurrence on the downward risk movement of stock markets over the globe (Goodell, 2020). Eventually, the event became the focus of research in the economic and financial context, specifically for the stock market research. 
Most of global stock markets overreacted and followed a highly volatile movement in March 2020, responding to the spread of COVID-19. Due to such panic selling and falling stock index values, in March and April 2020, the markets witnessed trading halts and multiple circuit breaks. Such hostile and alarming reactions were persistent in most stock markets worldwide.

The key question is to assess and quantify the impact of the outbreak of COVID-19 on the global stock markets. Keeping the previous literature on measuring the short-term impact of COVID-19 on stock markets (Liu et al., 2020; Mishra \& Mishra, 2020; Singh et al., 2020), the study considers the stock markets of G-7 and BRICS as the focus of investigation. The group of G-7 contributes more than $50 \%$ of the world's GDP, whereas BRICS accounts for more than 50\% of growth in the world GDP. Hence, the two groups of most predominant countries in the world economy are selected as the focus of this study. The comparison between G-7 and BRICS on the economic front is prevalent in the literature, but comparing their stock market's performance in the COVID period using an 'Event Study Methodology' makes the study unique.

\section{LITERATURE REVIEW}

A good tally of studies measuring the impact of COVID-19 on stock markets domestically and globally have considered varied sample based on continents, most affected countries, emerging markets, developed and developing countries (Ahmad Siddiqui et al., 2020; Ali et al., 2020; Aslam et al., 2021; Izzeldin et al., 2021; Okorie \& Lin, 2020; Zaremba et al., 2020). Further, the literature review is presented under three sub-headings to stream the paper's main idea and place research gaps.

\subsection{COVID-19 and stock markets}

COVID-19, being a health pandemic, inflicted the global stock markets in unprecedented ways (Goodell, 2020). Along with the pause in economic activities, the panic, fear, and uncertainty adversely impacted markets, discernible in the nosedive of the major stock markets over the globe (Okorie \& Lin, 2021). The world has experienced epidemics and pandemics like SARS, EBOLA, and MERS before COVID-19, but COVID-19 affected stock markets in the most hazardous way, both in intensity and scale (David et al., 2021).

The rapid spread of the contagious disease outside China, initially to Europe and then to the USA, has resulted in the free fall of the major indices worldwide (Ali et al., 2020). The impact of panic caused by COVID-19 is reflected in high frequency of searches for keywords of the Google Search Index for coronavirus. As a proxy of panic and stress, the search frequency significantly explained the shocks in the US stock market (Azimli, 2020; Lyócsa \& Molnár, 2020). Cao et al. (2020) exhibited the influencing effect of confirmed cases and death cases of COVID-19 inside and surrounding the country on their stock markets.

Topcu and Gulal (2020) studied the impact of COVID-19 on emerging markets and found that Asian stock markets were more severely affected than European emerging markets. COVID-19 appalled the stock markets significantly compared to economic events such as GST implementation and demonetization in India (Mishra et al., 2020). All the above significant findings pave the way to further introspection of the methods that can be adopted for measuring and comparing the effect of COVID-19 on stock markets.

\subsection{The event study approach}

Mishra and Mishra (2020) investigated the impact of COVID-19 in the selected Asian countries surrounding China, using an event study approach based on the market model, to estimate expected return and Cumulative Abnormal Returns (CAR). They found a significant negative impact of COVID-19 on all the 12 sample indices in the event window. The use of the event study method to measure the effect of COVID-19 in the hardest-hit countries (Liu et al., 2020), the G-20 countries (Singh et al., 2020) is quite evident in the literature.

The event study method was first coined to measure the impact of corporate events like the an- 
nouncement of dividend payment, stock split, bonus shares, and merger and acquisition on the individual stocks (Fama et al., 1969). The event study application eventually became more prevalent as an analytical tool to measure the impact of firm-specific events on their monthly and daily stock returns (Boehmer et al., 1991; Brown \& Warner, 1985), in continuation previous research on a similar systematic event at a macro level.

Trends such as SARS and its impact on Taiwan stock market were well captured by the event study technique (Chen et al., 2009; Chen et al., 2018). In contrast, Bash and Alsaifi (2019) endeavored to capture the impact of a socio-political event in the Saudi Stock Exchange. The trend to measure the effect of economic events on the stock markets remained witnessed in the literature (Alam et al., 2020; Pendell \& Cho, 2013). Whereas, mean adjusted model, market-adjusted model, and market models for estimating expected returns are invariably applied in conjunct with the event study (Brown \& Warner, 1985; Singh et al., 2020). However, the choice of CAR, BHAR, CAAR, and ABHAR for measuring the cumulative impact in the event window depends on the nature, length scale, and intensity of such an event (Dutta, 2014). The vast and diverse literature on the event study methodology provides the rationale and theoretical background for choosing and customizing the methodology for this study.

\subsection{G-7 vs BRICS}

A renewed repetitive comparison of the current global economic power (G7) with BRICS nations in economic, social, and political aspects is customary in the existing academic literature (Mahmood, 2015; Singhania \& Saini, 2018). The G-7 countries are considered global leaders of the modern economic era, who are incessantly challenged by the BRICS in the economic and financial performance (Kilic \& Cankaya, 2020; Shahrokhi et al., 2017). Since after Russia left as the member of G-7 in 2015, there are no common members in BRICS and G-7, as they became ideal competitors for comparative evaluation as economic groups (Song et al., 2019; Wang et al., 2020; Yang et al., 2018; Zhang et al., 2013).

Traces from the literature provide insight into an event study being majorly used to capture the im- pact of unsystematic risk and its deep-down effect on the individual stocks and industries (Alam et al., 2020; Lyócsa \& Molnár, 2020; Mishra et al., 2020). A sufficient count of previous studies focusing on the cross-country comparison of stock markets' reactions to COVID-19 (David et al., 2021; Mishra \& Mishra, 2020; Topcu \& Gulal, 2020) imitates the appropriateness of the event study method. Deficient documentation in the research wits shoves the path to measure and analyze the impact of macro events such as COVID-19 on the G-7 and BRICS nations, which propounds the idea of this study.

\section{AIMS}

The paper aims to quantify and compare the impact of COVID-19 on the stock markets of G-7 and BRICS as individual countries and economic groups using an event study methodology. The study also attempts to check the intra-group coherence of G-7 and BRICS nations' stock markets during the coronavirus pandemic period.

\section{METHODOLOGY AND DATA}

The event study methodology is adopted to measure the impact of COVID-19 on stock markets of BRICS and G7 nations. The choice of the event study methodology allows capturing the effect of an event at both the country level and the economic group level. The methodology was propounded to measure the firm-level impact on the stock prices and their movements. Implementing the event study methodology on such a systematic global event requires methodological customization to measure the impact created accurately. The use of stochastically sound Market Adjusted Model \& the Market Model is not theoretically appropriate, as the event would also similarly impact the benchmark index. The loss of information of such shocks may mislead the value of the abnormal return. In such conditions, the use of a mean adjusted model is more appropriate as it captures all the movements in the stock indices in the form of systematic effect.

The index value data is collected from Investing. com, an open-source website providing the data 
of all the major stock markets worldwide. The following indices, representing the individual countries of G-7 and BRICS with their registered stock exchanges, are shown in Table 1.

Table 1. List of countries, representative indices, and stock markets

Source: Authors.

\begin{tabular}{|c|c|c|}
\hline Country & Index & Stock market \\
\hline \multicolumn{3}{|c|}{ G-7 nations } \\
\hline Canada & TSX 60 & Toronto Stock Exchange \\
\hline France & CAC 40 & Paris Stock Exchange \\
\hline Germany & DAX & Frankfurt Stock Exchange \\
\hline Italy & FTSEMIB & Borsa Italiana \\
\hline Japan & Nikkei 225 & Tokyo Stock Exchange \\
\hline United Kingdom & FTSE 100 & London Stock Exchange \\
\hline $\begin{array}{l}\text { United States of } \\
\text { America }\end{array}$ & S\&P 500 & The New York Stock Exchange \\
\hline \multicolumn{3}{|c|}{ BRICS } \\
\hline Brazil & BVSP & Brazil Bolsa Balcao \\
\hline Russia & MOEX & Moscow Exchange \\
\hline India & NIFTY 50 & $\begin{array}{l}\text { National Stock Exchange of } \\
\text { India }\end{array}$ \\
\hline China & SSEC & Shanghai Stock Exchange \\
\hline South Africa & JTOPI & Johannesburg Stock Exchange \\
\hline
\end{tabular}

\subsection{Event date}

COVID-19 caught the world's attention for the first time on January 20, 2020 when it was reported by Zhong Nanshan (High level leading expert of NHFC of China) as a transmittable novel virus, which may spread across the globe. This news soon became headlines in the global media. Therefore, being the first event in the line of multiple subevents, the news outbreak has inspired this study to select it as an event date to capture the effect of subsequent sub-events related to COVID-19. This event date's choice is consistent with the previous literature on the impact of COVID-19 on stock markets (Balmfordet et al., 2020; Liu et al., 2020; Singh et al., 2020).

\subsection{Event window}

To capture the global pandemic's consequential effect on the stock indices, a 90-day event window is selected, starting from the day of the announcement about the transmittable disease and 89 days after that. Related studies show that the influence of COVID-19 on returns of stocks is longer than the impact due to corporate announcements (Liu et al., 2020; Singh et al., 2020). This study reiterates that this medical catastrophe is not a single event; instead, it is a series of events with global impact. Hence, to capture the impact of COVID-19 in different periods of the pandemic, the event window is further broken into six-event windows of 15 days each: (0-14), (15-29), (30-44), (45-59), (60$74)$, and (75-89) days, respectively.

\subsection{Estimation window}

The estimation window is used to calculate the expected returns for the event study. In this study, the estimation window is 120 trading days, considering from day -120 to day -1 , where the day 0 is when the information about the coronavirus floated in the open media.

\subsection{Impact measurement}

To measure the event's impact at the country level, Abnormal Returns (AR) and Buy and Hold Abnormal Returns (BHAR) are used. While capturing the impact at the group level, Average Abnormal Returns (AAR) and Average Buy and Hold Abnormal Returns (ABHAR) of the representing benchmark index are considered. The use of BHAR and ABHAR is not frequent in the event study methodology of small durations. However, looking on to the scale of daily abnormal returns, the compounded measure of BHAR and ABHAR is mathematically and economically much superior to the simple addition nature of CAR and CAAR in portraying the actual economic impact (Hull et al., 2018) (see Appendix B).

\subsection{Daily stock returns}

$$
R_{i, t}=\ln \left[\frac{P_{i, t}}{P_{i, t-1}}\right] \cdot 100,
$$

where $R_{i, t}$ is the return of index $i$ at time $t, P_{i, t}$ is the price of index $i$ on current day, and $P_{i, t-1}$ is the price of index $i$ at the immediate previous trading day $t$.

$$
E\left(\bar{R}_{i}\right)=\frac{1}{N} \sum_{-120}^{-1} R_{i, t} .
$$

Equation (2) derives the mean expected returns $E\left(\bar{R}_{i}\right)$ for index $i$, where $R_{i, t}$ is the dai- 
ly log-normal returns of the index $i$ in the estimation window, i.e., $(-120$ to -1$)$. Further, $E\left(\bar{R}_{i}\right)$ shall be used as standard returns to estimate abnormal movements of indices in the event window.

$$
A R_{i, t}=R_{i, t}-E\left(\bar{R}_{i}\right)
$$

To capture the impact of the event on individual stock indices every day in the event window as abnormal returns $(A R) . A R_{i, t}$ of index $i$ at time $t$ is the difference between the realized return and mean expected returns $E\left(\bar{R}_{i}\right)$ of index $i$ in the event window denoted by equation (3).

$$
\begin{aligned}
& \operatorname{BHAR}\left(t_{1}, t_{2}\right)=\prod_{t_{1}-1}^{t_{2}}\left(1+R_{i, t}\right)- \\
& -\prod_{t_{1}-1}^{t_{2}}\left(1+E\left(\bar{R}_{i}\right)\right) .
\end{aligned}
$$

Equation (4) captures the event's total impact in the specific event windows as BHAR value (Sitthipongpanich, 2011). BHAR is the difference between the buy and hold realized returns and the buy and hold expected returns for the event window $\left(t_{1}, t_{2}\right)$. Equation (5) represents the Average Abnormal Returns $\left(A A R_{g, t}\right)$ of the group $g$ at time $t$. $A A R$ represents the daily arithmetic mean of all the indices in the group.

$$
A A R_{g, t}=\frac{1}{N} \sum_{i=1}^{N} A R_{i, t} \text {. }
$$

Average buy and hold returns are estimated as the arithmetic mean of $B H A R_{i, t}$ of individual index $i$, where $N$ is the number of indices in the estimation group.

$$
\operatorname{ABHAR}\left(t_{1}, t_{2}\right)=\frac{1}{N} \sum_{t_{1}}^{t_{2}} B H A R_{i, t} .
$$

The $t$-statistics is used to measure the significance of $A A R$ and $A B H A R$ every day $t$, in the event window $\left(t_{1}, t_{2}\right)$. The abbreviation is as followed in Equations (7) and (8):

$$
t-\text { Test }_{A A R}=\frac{A A R_{t, g}}{\sigma\left(A A R_{g}\right)},
$$

where $A A R_{t, g}$ is average abnormal returns and $A B H A R_{t, g}$ (G7 or BRICS) at time $t$ and $\sigma\left(A A R_{g}\right)$ is the standard deviation of average abnormal returns of group $g$ in the window estimation period $(-120$ to -1$)$.

$$
t-\operatorname{Test}_{A B H A R}=\frac{A B H A R_{t, g}}{\sigma\left(A A R_{t, g}\right) \cdot\left(\sqrt{t_{2}-t_{1}+1}\right)}
$$

where

$$
\sigma\left(A A R_{g}\right)=\sqrt{\sum_{-120}^{-1} \frac{(A A R)^{2}}{120}} .
$$

\section{RESULTS AND DISCUSSION}

The movement and reactions of abnormal returns are shown in Figures 1 and 2 for G-7 and BRICS nations, respectively (see Figures 1 and 2). The initial phase of the event window follows an imminent path until the 21st day, which reflects low volatility and neutral returns. It is followed by a highly volatile negative cluster formulated between the $21^{\text {st }}$ day and $42^{\text {nd }}$ day of the observation window covering the free fall, reflecting the panic and stress in the stock markets across all stock markets. From the $42^{\text {nd }}$ day, the markets showed signs of recovery with positive abnormal returns clustered till the $58^{\text {th }}$ day. The stock markets' responses as ARs remained upbeat with a hint of volatility in the remaining observation window till the $89^{\text {th }}$ day.

\subsection{Mean returns and standard deviation of G-7 and BRICS nations}

Table 2 presents the mean returns and standard deviations for the G-7 and BRICS, where Panel A covers the estimation window of 120 days, while Panel B covers 90 days of the event window. All the indices of G-7 and BRICS except FTSE (UK) showed positive mean returns in the estimation window. While negative mean returns in the event window portray the effect of deadly coronavirus. The higher standard deviation of the indices represents higher volatility in the event window compared to the estimation window. BVSP, TSX 60, FTSEMIB, and S\&P 500 showed the most volatility in the event window as the countries are most affected after China. Despite China being the centre of the COVID-19 outbreak, SSEC $(-0.054 \%)$ shows a relatively lower negative mean return than other stock indices. This may be ascribed to the virus containment and government interventions. Further, in the results, the standard 


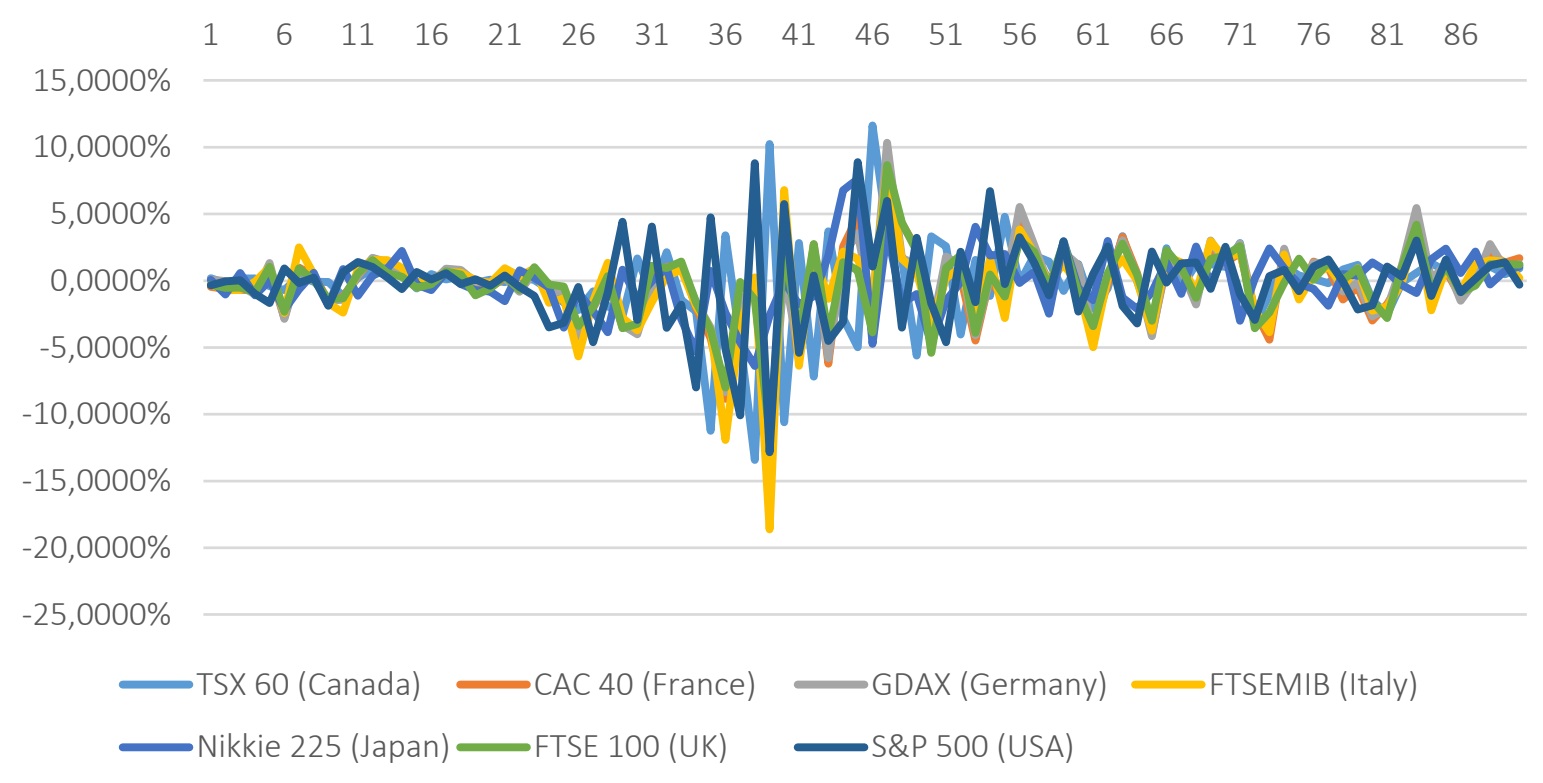

Figure 1. Abnormal returns for G-7 in the observation window (0-89)

deviation is reported. The standard deviation in the estimation window should be used to evaluate changes in the market volatility during the observation window and the six sub-event windows.

\subsection{Buy and hold abnormal returns in the event window (0-14)}

Table 3 presents the BHAR values of all the sample indices in the initial window of the event study, along with the standard deviation and t-statistics. In the first event window of 15 days, all stock in- dices showed negative BHAR values signifying a downward trend of realized returns except for Italy's case. Italy showed positive $0.455 \%$ returns in the event window. The negative BHAR is statistically significant at a $95 \%$ confidence interval for Russia, with MOEX losing its value by $-5.529 \%$. All stock indices negatively responded to the news of COVID-19, but the BHAR values were not significant for any stock market except for MOEX (Russia). Standard deviation represents the volatility of indices in the respective event windows.

Source: Authors.

AR for BRICS countries

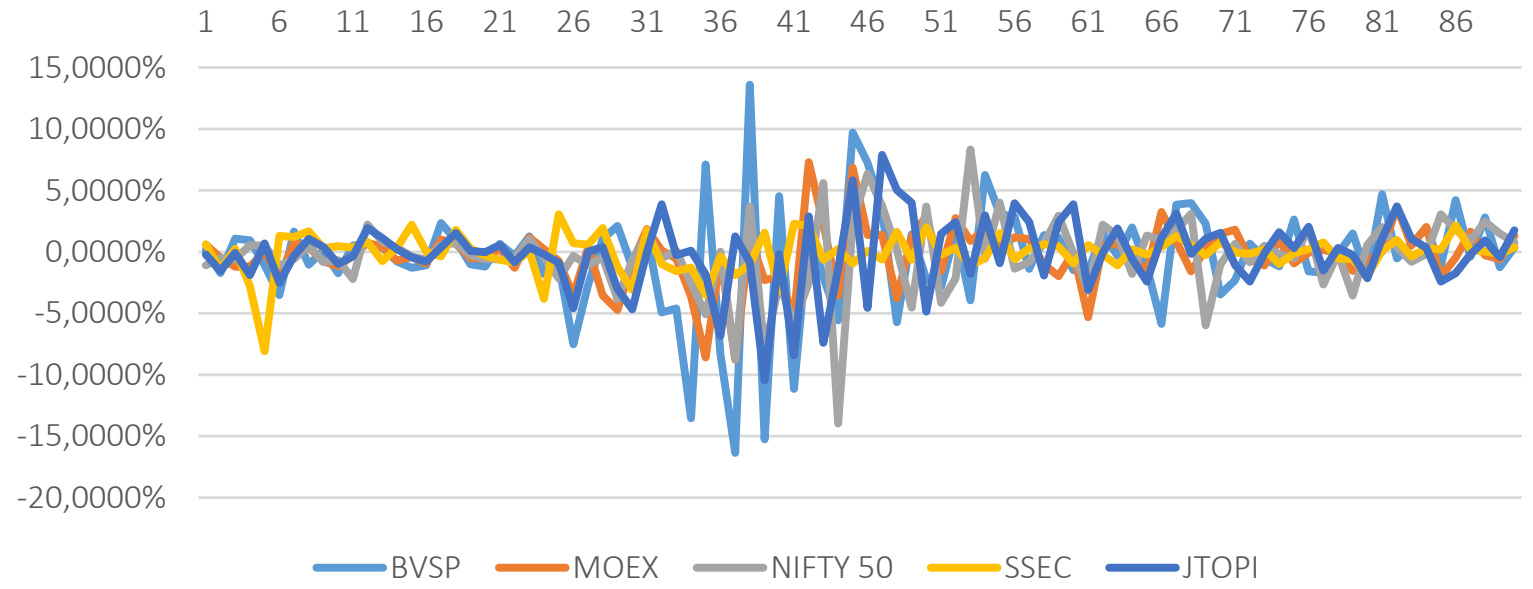

Figure 2. Abnormal returns for BRICS in the observation window (0-89) 
Table 2. Mean returns and standard deviation of G-7 and BRICS

Source: Authors.

\begin{tabular}{|c|c|c|c|c|c|}
\hline \multicolumn{6}{|c|}{ Panel A. Estimation period of 120 trading days before $20-01-2020$} \\
\hline \multicolumn{3}{|c|}{ BRICS } & \multicolumn{3}{|c|}{ G-7 } \\
\hline Indices (BRICS) & $\begin{array}{c}\text { Estimation } \\
\text { window std. dev } \\
(\%) \\
\end{array}$ & $\begin{array}{l}\text { Estimation } \\
\text { window mean } \\
\text { returns (\%) }\end{array}$ & Indices (G-7) & $\begin{array}{c}\text { Estimation } \\
\text { window std. dev } \\
(\%)\end{array}$ & $\begin{array}{l}\text { Estimation } \\
\text { window mean } \\
\text { returns (\%) }\end{array}$ \\
\hline BVSP & 1.053 & 0.109 & TSX 60 & 0.491 & 0.050 \\
\hline MOEX & 0.706 & 0.136 & CAC 40 & 0.876 & 0.085 \\
\hline NIFTY 50 & 0.943 & 0.065 & DAX & 0.881 & 0.075 \\
\hline SSEC & 0.819 & 0.054 & FTSEMIB & 0.962 & 0.079 \\
\hline \multirow[t]{3}{*}{ JTOPI } & 0.889 & 0.028 & Nikkei 225 & 0.834 & 0.111 \\
\hline & & & FTSE & 0.790 & -0.001 \\
\hline & & & S\&P 500 & 0.804 & 0.081 \\
\hline \multicolumn{6}{|c|}{ Panel B. Event window of 90 trading days from $20-01-2020$ to $03-06-2020$} \\
\hline Indices (BRICS) & $\begin{array}{l}\text { Event window } \\
\text { std. dev (\%) }\end{array}$ & $\begin{array}{c}\text { Event window } \\
\text { mean returns (\%) }\end{array}$ & Indices (G-7) & $\begin{array}{c}\text { Event window std. } \\
\operatorname{dev}(\%)\end{array}$ & $\begin{array}{c}\text { Event window } \\
\text { mean returns (\%) }\end{array}$ \\
\hline BVSP & 4.447 & -0.341 & TSX 60 & 3.372 & -0.137 \\
\hline MOEX & 2.399 & -0.155 & CAC 40 & 2.907 & -0.292 \\
\hline NIFTY 50 & 3.043 & -0.228 & DAX & 2.919 & -0.165 \\
\hline SSEC & 1.530 & -0.054 & FTSEMIB & 3.264 & -0.317 \\
\hline \multirow[t]{3}{*}{ JTOPI } & 2.832 & -0.118 & Nikkei 225 & 2.250 & -0.082 \\
\hline & & & FTSE & 2.623 & -0.234 \\
\hline & & & S\&P 500 & 3.306 & -0.105 \\
\hline
\end{tabular}

Note: ${ }^{* * *}$ represent significance at $1 \%, * *$ at $5 \%$, and $*$ at $10 \%$, respectively

Table 3. BHAR in the event window (0-14) for G-7 and BRICS

Source: Authors.

\begin{tabular}{|c|c|c|c|c|c|c|c|}
\hline \multicolumn{4}{|c|}{ BRICS } & \multicolumn{4}{|c|}{ G-7 } \\
\hline$(0-14)$ & STD (\%) & BHAR (\%) & $t$-stats & $(0-14)$ & STD & BHAR & t-stats \\
\hline BVSP & 1.325 & -5.814 & -1.421 & TSX 60 & 0.536 & -0.110 & -0.058 \\
\hline MOEX & 0.846 & $-5.529 * *$ & -2.014 & CAC 40 & 1.152 & -2.534 & -0.746 \\
\hline NIFTY 50 & 1.058 & -3.121 & -0.854 & DAX & 1.244 & -1.330 & -0.389 \\
\hline SSEC & 2.361 & -4.068 & -0.522 & FTSEMIB & 1.450 & 0.455 & 0.122 \\
\hline \multirow[t]{3}{*}{ JTOPI } & 1.198 & -3.056 & -0.887 & Nikkei 225 & 1.168 & -2.658 & -0.822 \\
\hline & & & & FTSE & 1.038 & -2.765 & -0.903 \\
\hline & & & & S\&P 500 & 0.949 & -0.612 & -0.196 \\
\hline
\end{tabular}

Note: ${ }^{* * *}$ represent significance at $1 \%, * *$ at $5 \%$, and $*$ at $10 \%$, respectively.

\subsection{Buy and hold abnormal returns in the event window (15-29)}

The buy and hold abnormal returns reciprocate a negative response in all the markets in the second 15-day window (see Table 4). All the markets have at least one confirmed COVID-19 case in the event window and are directly affected by the contagious virus's spread. The markets portrayed the panic in the economies with abnormal negative returns. BHAR values are significant except for China, which showed the lowest abnormality of -2.207 returns in the event window. It controlled the spread of COVID-19 by implementing strict lockdown and containment policies. Markets showed a loss in all the indices of the BRICS and G7 nations. CAC 40 (France) is losing the most in G7 $-13.5 \%$ and MOEX (Russia) in BRICS by $-12.7 \%$ in the second window. G7 countries had similar BHAR values between $-11 \%$ and $-14 \%$ except for Canada, which had a relatively low negative BHAR of about $-7 \%$. In contrast, the movement of BRICS countries were more diverse from $-0.6 \%$ in China to $-12.7 \%$ in Russia. BRICS nations show a much diverse response to COVID-19 than a synchronized and similar response by the G-7 countries. 
Table 4. BHAR in the event window (15-29) for G-7 and BRICS

Source: Authors.

\begin{tabular}{|c|c|c|c|c|c|c|c|}
\hline \multicolumn{4}{|c|}{ BRICS } & \multicolumn{4}{|c|}{ G-7 } \\
\hline$(15-29)$ & STD & BHAR & $t$-stats & $(15-29)$ & STD & BHAR & $t$-stats \\
\hline BVSP & 2.328 & $-9.705^{* * *}$ & -2.370 & TSX 60 & 1.171 & $-6.943^{* * *}$ & -3.648 \\
\hline MOEX & 1.764 & $-12.719 * * *$ & -4.634 & CAC 40 & 1.601 & $-13.426^{* * *}$ & -3.955 \\
\hline NIFTY 50 & 1.171 & $-9.079 * * *$ & -2.486 & DAX & 1.683 & $-13.371^{* * *}$ & -3.916 \\
\hline SSEC & 1.813 & -2.207 & -0.664 & FTSEMIB & 1.990 & $-11.666^{* * *}$ & -3.131 \\
\hline \multirow[t]{3}{*}{ JTOPI } & 1.853 & $-11.462 * * *$ & -3.329 & Nikkei 225 & 1.415 & $-13.368^{* * *}$ & -4.138 \\
\hline & & & & FTSE & 1.514 & $-12.040 * * *$ & -3.934 \\
\hline & & & & S\&P 500 & 2.150 & $-11.954 * * *$ & -3.842 \\
\hline
\end{tabular}

Note: ${ }^{* * *}$ represent significance at $1 \%, * *$ at $5 \%$, and $*$ at $10 \%$, respectively.

\subsection{Buy and hold abnormal returns in the event window (30-44)}

The fear and anxiety due to uncertainties surrounding the COVID-19 are notably visible in highly negative abnormal returns of all G-7 and BRICS nations' benchmark indices during the third window reported in Table 5. This window covers the surge in the cases in all the countries except China, where the virus's containment was successful. Panic in the markets is observable by the increased volatility compared to the volatility in the estimation window. With the most severe losses booked by BVSP (Brazil) of around $-40 \%$ in the BRICS nations and TSX 60 (Canada) with $-33 \%$ in G-7 nations, all the G-7 countries booked negative BHAR of more than $-20 \%$ except Nikkei 225 (Japan), which showed around $-10 \%$ losses in the event window. Consistent with the behavioral pattern, market indices of BRICS nations showed diverse returns from $-7.525 \%$ (SSEC) to $-40.28 \%$ (BVSP).

\subsection{Buy and hold abnormal returns in the event window (45-59)}

After being at the lowest value of the past 12 months, indices in both G-7 and BRICS show significant recovery in the fourth event window (see Table 6). Except for Japan, all the markets showed positive BHAR values, where Japan booked $-2.17 \%$ BHAR. Abnormality in the SSEC (China) remained insignificant as in previous windows. All the remaining positive returns were statistically and economically significant. Although high standard deviation hints at volatility in all the markets, in parallel, significant positive BHAR values point to the market correction after a panic nosedive. The market overreaction theory and market correction theory underpin the nosedive and fast recovery of the markets.

\subsection{Buy and hold abnormal returns in the event window (60-74)}

In contrast to the previous window, BRICS and G-7 countries show mixed reactions with positive and negative BHAR values across markets and groups. Volatility and BHAR values both have decreased in all the sample markets with no statistically significant abnormality (see Table 7). The maximum and minimum of $0.801 \%$ (SSEC) and $-2.323 \%$ (MOEX) compared to $2.706 \%$ (TSX 60) and $-3.832 \%$ (FTSEMIB) in the BRICS and G-7 group respectively, exhibits fading the impact of

Table 5. BHAR in the event window (30-44) for G-7 and BRICS

Source: Authors.

\begin{tabular}{|c|c|c|c|c|c|c|c|}
\hline \multicolumn{4}{|c|}{ BRICS } & \multicolumn{4}{|c|}{ G-7 } \\
\hline$(30-44)$ & STD & BHAR & $t$-stats & $(30-44)$ & STD & BHAR & $t$-stats \\
\hline BVSP & 8.895 & $-40.280 * * *$ & -9.839 & TSX 60 & 6.447 & $-33.664 * * *$ & -17.691 \\
\hline MOEX & 4.696 & $-16.121 * * *$ & -5.873 & CAC 40 & 4.938 & $-26.592 * * *$ & -7.835 \\
\hline NIFTY 50 & 5.198 & $-32.615^{* * *}$ & -8.931 & DAX & 4.537 & $-27.397 * * *$ & -8.025 \\
\hline SSEC & 2.053 & -7.525 & -1.336 & FTSEMIB & 6.218 & $-32.001 * * *$ & -8.59 \\
\hline \multirow[t]{3}{*}{ JTOPI } & 4.700 & $-22.660 * * *$ & -6.582 & Nikkei 225 & 3.956 & $-9.984^{* * *}$ & -3.09 \\
\hline & & & & FTSE & 4.064 & $-22.215^{* * *}$ & -7.26 \\
\hline & & & & S\&P 500 & 6.697 & $-22.435^{* * *}$ & -7.208 \\
\hline
\end{tabular}

Note: $* * *$ represent significance at $1 \%, * *$ at $5 \%$, and $*$ at $10 \%$, respectively. 
Table 6. BHAR in the event window (45-59) for G-7 and BRICS

Source: Authors.

\begin{tabular}{|c|c|c|c|c|c|c|c|}
\hline \multicolumn{4}{|c|}{ BRICS } & \multicolumn{4}{|c|}{ G-7 } \\
\hline$(45-59)$ & STD & BHAR & $t$-stats & $(45-59)$ & STD & BHAR & $t$-stats \\
\hline BVSP & 3.530 & $10.586^{* * *}$ & 2.585 & TSX 60 & 3.956 & $23.499 * * *$ & 12.349 \\
\hline MOEX & 1.826 & $6.596 * * *$ & 2.403 & CAC 40 & 3.395 & $9.530 * * *$ & 2.808 \\
\hline NIFTY 50 & 3.688 & $16.531^{* * *}$ & 4.526 & DAX & 3.557 & $17.525^{* * *}$ & 5.1336 \\
\hline SSEC & 0.941 & 2.199 & 0.488 & FTSEMIB & 2.960 & $9.719 * * *$ & 2.609 \\
\hline \multirow[t]{3}{*}{ JTOPI } & 3.597 & $23.824 * * *$ & 6.921 & Nikkei 225 & 2.723 & -2.178 & -0.674 \\
\hline & & & & FTSE & 3.582 & $10.565^{* * *}$ & 3.452 \\
\hline & & & & S\&P 500 & 3.322 & $11.588^{* * *}$ & 3.723 \\
\hline
\end{tabular}

Note: ${ }^{* * *}$ represent significance at $1 \%,{ }^{* *}$ at $5 \%$, and $*$ at $10 \%$, respectively.

Table 7. BHAR in the event window (60-74) for G-7 and BRICS

Source: Authors.

\begin{tabular}{|c|c|c|c|c|c|c|c|}
\hline \multicolumn{4}{|c|}{ BRICS } & \multicolumn{4}{|c|}{ G-7 } \\
\hline$(60-74)$ & STD & BHAR & t-stats & $(60-74)$ & STD & BHAR & t-stats \\
\hline BVSP & 2.764 & -0.231 & -0.056 & TSX 60 & 2.017 & 2.706 & 1.422 \\
\hline MOEX & 1.968 & -2.323 & -0.846 & CAC 40 & 2.512 & -3.717 & -1.095 \\
\hline NIFTY 50 & 2.288 & -2.061 & -0.291 & DAX & 2.591 & -2.444 & -0.715 \\
\hline SSEC & 0.636 & 0.801 & 0.277 & FTSEMIB & 2.508 & -3.832 & -1.028 \\
\hline \multirow[t]{3}{*}{ JTOPI } & 1.765 & 0.494 & 0.143 & Nikkei 225 & 1.826 & 2.252 & 0.697 \\
\hline & & & & FTSE & 2.244 & 0.665 & 0.217 \\
\hline & & & & S\&P 500 & 1.827 & 0.874 & 0.28 \\
\hline
\end{tabular}

Note: $* * *$ represent significance at $1 \%, * *$ at $5 \%$, and $*$ at $10 \%$, respectively.

COVID-19 and panic across markets. Even after obtaining normalized BHAR in this event window, this study continues analyzing the final window to capture any late reactions in the markets and to confirm netting all market reactions related to the event.

\subsection{Buy and hold abnormal returns in the event window (75-89)}

Positive BHAR values across all the indices of G-7 and BRICS reveal a clear picture of markets being entirely out of the negative influence of the COVID-19 pandemic. Table 8 reports significant positive BHAR in Brazil, India, Japan, Germany, and the UK as $7.339 \%, 8.135 \%, 8.452 \%, 7.810 \%$, and $6.130 \%$, respectively. Similarly, positive BHAR values in MOEX, SSEC, JTOPI and TSX 60, CAC 40, FTSEMIB, and S\&P 500 reported positive $2.241 \%$, $3.398 \%, 4.198 \%, 1.480 \%$, 3.891\%, 2.294\%, 4.980\%. The recovery in all the countries' stock markets is observable in the significantly positive BHAR values in the last event window (75-89). The positive BHAR values resulted due to the governments' intervention as economic easement, relief packages, strict lockdown, and containing the spread of COVID-19. The reduced panic and volatility in the market are the outcome of available reliable

Table 8. BHAR in the event window (75-89) for G-7 and BRICS

\begin{tabular}{|c|c|c|c|c|c|c|c|}
\hline \multicolumn{4}{|c|}{ BRICS } & \multicolumn{4}{|c|}{ G-7 } \\
\hline$(75-89)$ & STD & BHAR & $t$-stats & $(75-89)$ & STD & BHAR & $t$-stats \\
\hline BVSP & 2.054 & 7.339* & 1.792 & TSX 60 & 1.071 & 2.241 & 1.177 \\
\hline MOEX & 1.439 & 3.398 & 1.238 & CAC 40 & 1.934 & 4.198 & 1.236 \\
\hline NIFTY 50 & 1.826 & $8.135^{* *}$ & 2.227 & DAX & 1.991 & $8.452 * * *$ & 2.475 \\
\hline SSEC & 0.996 & 1.480 & 0.512 & FTSEMIB & 1.657 & 3.891 & 1.044 \\
\hline \multirow[t]{3}{*}{ JTOPI } & 1.690 & 2.294 & 0.666 & Nikkei 225 & 1.165 & $7.810 * * *$ & 2.417 \\
\hline & & & & FTSE & 1.609 & $6.130 * *$ & 2.003 \\
\hline & & & & S\&P 500 & 1.421 & 4.980 & 1.601 \\
\hline
\end{tabular}

Note: $* *$ represent significance at $1 \%, * *$ at $5 \%$, and $*$ at $10 \%$, respectively 


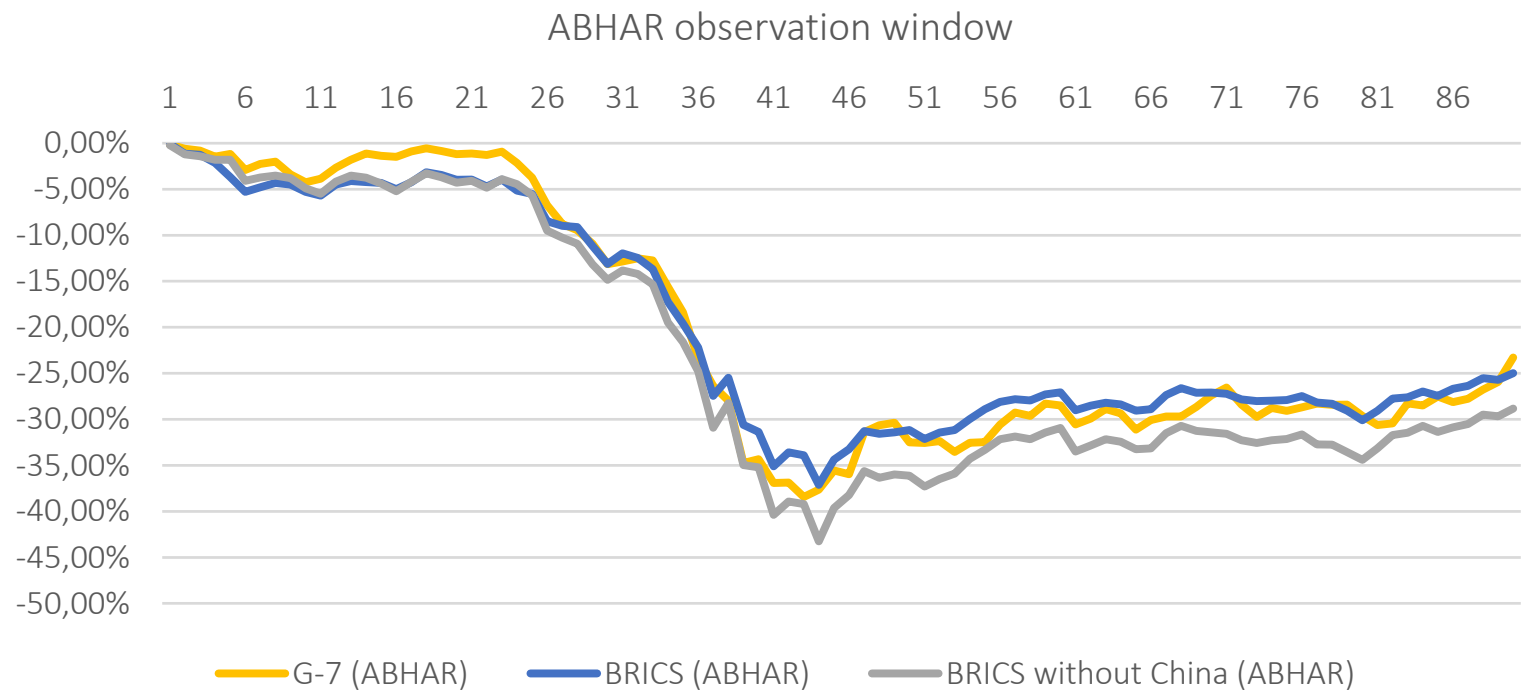

Figure 3. ABHAR values in the observation window for G-7 and BRICS

information about COVID-19 to the typical human information terrain worldwide. The available information settled the anxiety and the fear of the unknown in the stock markets.

ABHAR values are used to quantify the event's average abnormal effect for both G-7 and BRICS as groups during the observation window. Two distinct phases of the calculated ABHAR values were observed in the form of steep fall and recovery. Till the $42^{\text {nd }}$ day for G-7 and $43^{\text {rd }}$ day for BRICS, both the groups witness increasing negative ABHAR value to their lowest of $-38.43 \%$ and $-37.12 \%$, respectively. In the second phase, the markets show recovery with ABHAR values as $-23.29 \%$ and $-25.00 \%$ on the last day of the event window respective for G-7 and BRICS.

Appendix A reports that the ABHAR value for BRICS nations exhibits $-43.26 \%$ and $-28.84 \%$ without considering China on the $43^{\text {rd }}$ and $89^{\text {th }}$ day of the observation window. Table A1 shows that the similar-looking portfolios of BRICS and G-7 have quite different responses when controlled for China as a sample country. To explain the difference in the ABHAR values, this study verified China's insignificant abnormal returns across all the event windows. China positively influences the ABHAR values of BRICS in both the phases of the event window, pointing to the need for an investigation to determine such response factors. Above all, the difference in the ABHAR values caused by China in the BRICS is observable in the trends reported in Figure 3, i.e., around 6\% across the event horizon.

Finally, in continuation of the event study's findings, where the in-group response of stock markets is not synchronized in BRICS, this study tried to verify interrelation in the markets during the

Table 9. Correlation matrix of G-7 nations in the estimation period and event window

Source: Authors.

\begin{tabular}{|c|c|c|c|c|c|c|c|}
\hline Estimation window & TSX 60 & CAC 40 & DAX & FTSEMIB & Nikkei 225 & FTSE 100 & S\&P 500 \\
\hline$T S \times 60$ & 1.00000 & -0.18353 & -0.11641 & -0.23072 & -0.00158 & -0.16258 & -0.43807 \\
\hline CAC 40 & 0.18521 & 1.00000 & 0.97697 & 0.91178 & 0.26403 & 0.94530 & 0.48238 \\
\hline$D A X$ & 0.02767 & 0.04098 & 1.00000 & 0.90896 & 0.25951 & 0.93820 & 0.48100 \\
\hline FTSEMIB & 0.21297 & 0.11071 & 0.49411 & 1.00000 & 0.25695 & 0.89198 & 0.54584 \\
\hline Nikkei 225 & 0.08655 & -0.08732 & 0.08608 & 0.16279 & 1.00000 & 0.24404 & 0.35072 \\
\hline FTSE 100 & 0.36666 & 0.46773 & -0.12242 & 0.00401 & -0.05615 & 1.00000 & 0.42082 \\
\hline$S \& P 500$ & 0.06944 & 0.30013 & -0.15765 & -0.12184 & -0.04348 & 0.51493 & 1.00000 \\
\hline
\end{tabular}

Note: Event window. Estimation window 
Table 10. Correlation matrix of BRICS nations in the estimation period and event window

\begin{tabular}{|c|c|c|c|c|c|}
\hline Estimation window & BVSP & MOEX & NIFTY 50 & SSEC & JTOPI \\
\hline BVSP & 1.00000 & 0.39543 & 0.40836 & -0.06263 & 0.34926 \\
\hline MOEX & 0.12550 & 1.00000 & 0.46993 & 0.14644 & 0.34980 \\
\hline NIFTY 50 & 0.02449 & 0.02901 & 1.00000 & 0.02962 & 0.10460 \\
\hline SSEC & -0.03647 & -0.00173 & 0.13305 & 1.00000 & -0.05642 \\
\hline JTOPI & 0.13230 & 0.25608 & 0.02169 & 0.10150 & 1.00000 \\
\hline
\end{tabular}

Note: Event window. Estimation window.

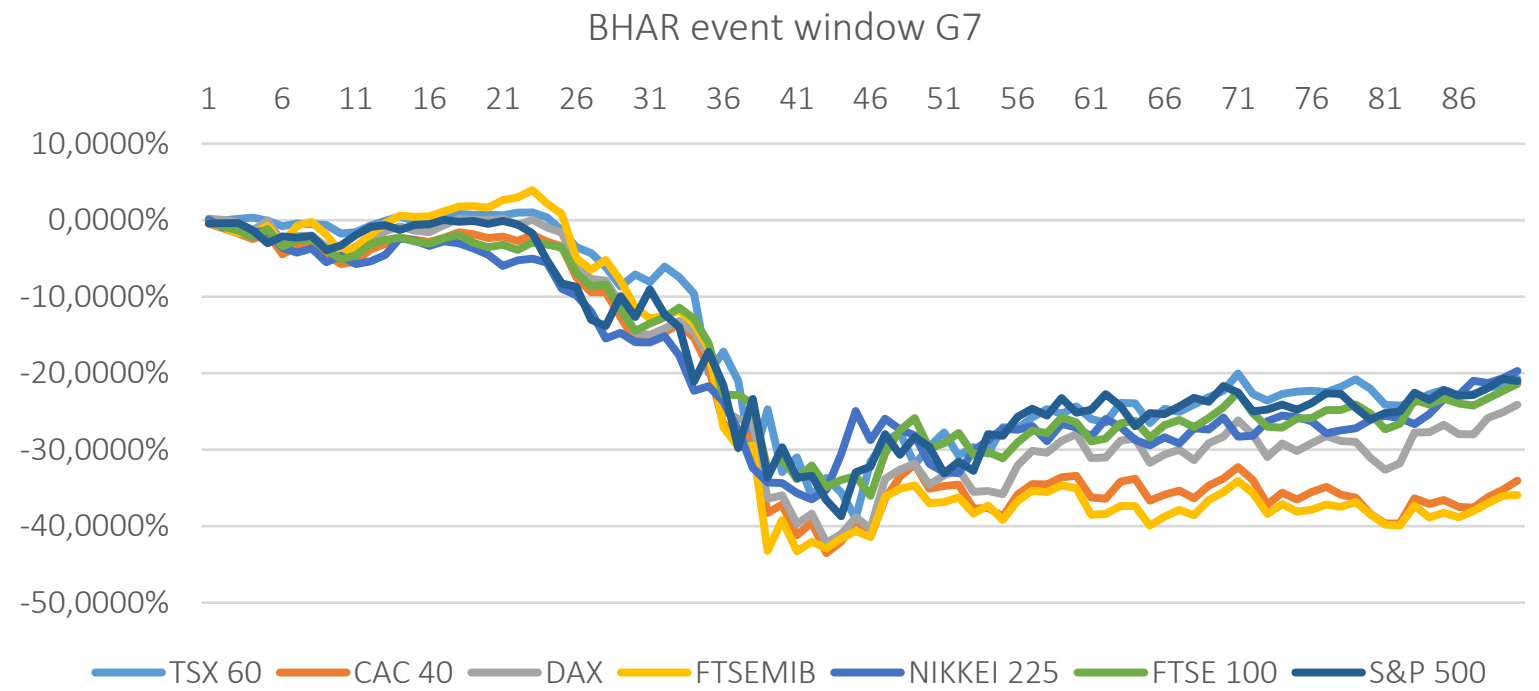

Figure 4. BHAR of G-7 nations for the observation window

BHAR event window BRICS

Source: Authors.

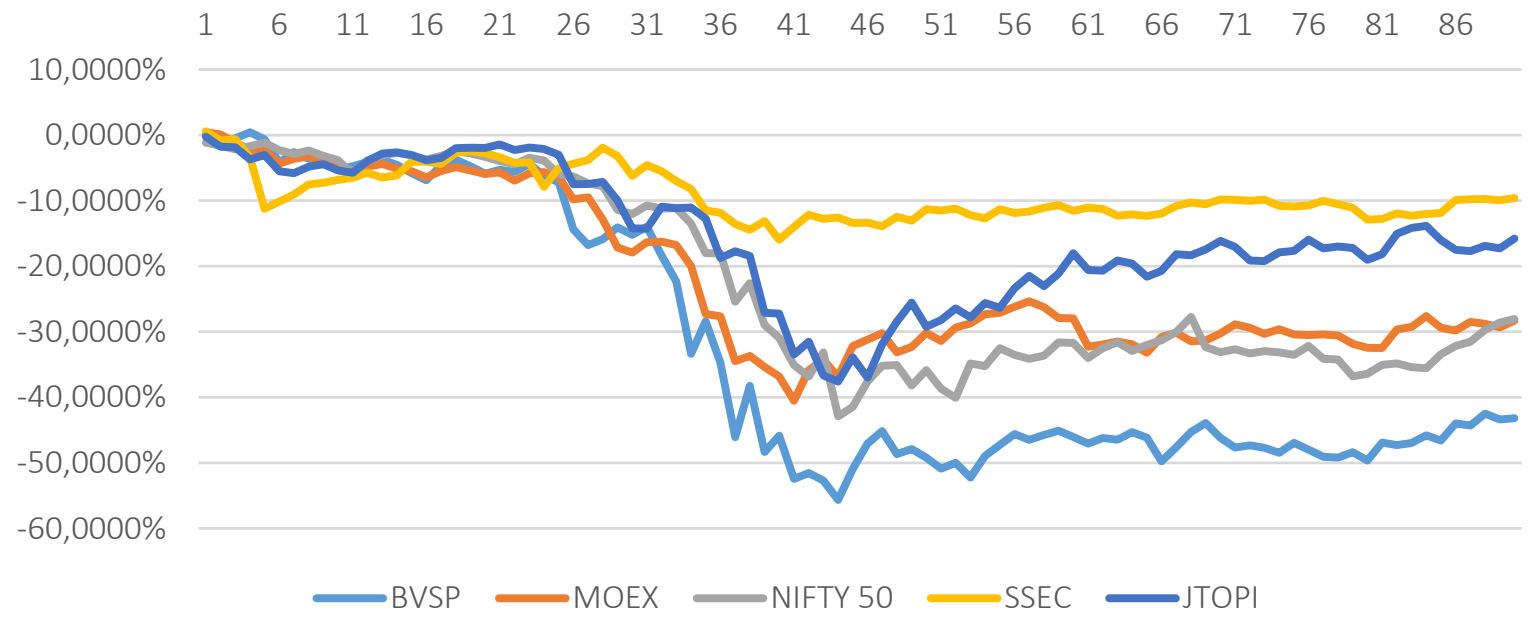

Figure 5. BHAR of BRICS nations for the observation window

event window. For this purpose, correlation matrices are presented to compare the integration of the markets in the estimation window $(-120$ to -1 days) and event window (0-89 days). Separate cor- The observation window witnesses an increased relation matrices report G-7 (Table 9) and BRICS correlation compared to the estimation window. 
Correlation confirms the integration of the markets, where the post effect of the systematic event has synchronized the markets. Both groups witnessed increased correlation except China (SSEC) in the BRICS nation, which is in line with Zhang et al. (2020). An increase in the correlation of
Abnormal Returns in the G-7 countries is more than that of the BRICS nations. The same can be observed in Figure 4. BHAR value of the indices in the G-7 nations looks more synchronized compared to the BRICS nations, which confirms a diverse effect of COVID-19.

\section{CONCLUSION AND FUTURE RESEARCH SCOPE}

This study aims to quantify and compare the impact of COVID-19 on the stock markets of G-7 and BRICS as individual countries and economic groups. The choice of the event study helps to identify the impact of COVID-19 at both the country and group level, like BHAR and ABHAR, respectively. The study also argues for the use of BHAR instead of CAR due to the high intensity of return abnormality during the COVID period. Mathematically, BHAR portrays very accurate results, which provides clarity in the estimation of the impact measurement.

All stock markets showed an appalling reaction during the 90-day event window, which was most significant in the third event window (30-44 days) after the event date. Significant BHAR values confirm the negative effect of COVID-19 across all the G-7 and BRICS countries except for China. Despite being the centre of such a shocking pandemic, the impact on the Chinese Benchmark Index (SSEC) remained insignificant in all event windows pointing towards substantial government steps to contain the virus. Results show diverse BHAR values from indices of BRICS nations compared to a synchronized response of G-7 nations, despite similar ABHAR values in the event window.

Given the different responses from the BRICS nations reported in this study, the reasons for the diverse BHARs during COVID-19 need to be determined in future research. The findings also indicate the use of BRICS as an international indices' portfolio for diversifying pandemic risk along with geographical and economic risk for international investors in managing country risks. The claims need to be further tested empirically by future researchers, considering BRICS and G-7 as index portfolios, evaluating the trade-off for the systematic risk of future pandemic situations.

\section{AUTHOR CONTRIBUTIONS}

Conceptualization: Sanket Ledwani.

Data curation: Sanket Ledwani.

Formal analysis: Sanket Ledwani.

Investigation: Sanket Ledwani, Suman Chakraborty.

Methodology: Sanket Ledwani, Suman Chakraborty.

Project administration: Sanket Ledwani, Sandeep S. Shenoy.

Resources: Sanket Ledwani, Suman Chakraborty, Sandeep S. Shenoy.

Software: Sanket Ledwani.

Supervision: Suman Chakraborty, Sandeep S. Shenoy.

Validation: Sanket Ledwani, Suman Chakraborty.

Visualization: Sanket Ledwani.

Writing - original draft: Sanket Ledwani.

Writing - review \& editing: Suman Chakraborty, Sandeep S. Shenoy. 


\section{REFERENCES}

1. Ahmad Siddiqui, T., Ahmed, H., \& Naushad, M. (2020). Diffusion of COVID-19 impact across selected stock markets: a wavelet coherency analysis. Investment Management and Financial Innovations, 17(4), 202214. https://doi.org/10.21511/ imfi.17(4).2020.19

2. Alam, M. M., Wei, H., \& Wahid, A. N. M. (2020). COVID-19 outbreak and sectoral performance of the Australian stock market: An event study analysis. Australian Economic Papers. https://doi. org/10.1111/1467-8454.12215

3. Alam, M. N., Alam, M. S., \& Chavali, K. (2020). Stock market response during COVID-19 lockdown period in India: An event study. Journal of Asian Finance, Economics and Business, 7(7), 131-137. https://doi. org/10.13106/jafeb.2020.vol7. no7.131

4. Ali, M., Alam, N., \& Rizvi, S. A. R. (2020). Coronavirus (COVID-19) - An epidemic or pandemic for financial markets. Journal of Behavioral and Experimental Finance, 27, 100341. https://doi. org/10.1016/j.jbef.2020.100341

5. Aslam, F., Ferreira, P., Mughal, K. S., \& Bashir, B. (2021). Intraday volatility spillovers among european financial markets during COVID-19. International Journal of Financial Studies, 9(1), 1-19. https://doi.org/10.3390/ ijfs 9010005

6. Azimli, A. (2020). The impact of CO VID-19 on the degree of dependence and structure of riskreturn relationship: A quantile regression approach. Finance Research Letters, 36. https://doi. org/10.1016/j.frl.2020.101648

7. Balmford, B., Annan, J. D., Hargreaves, J. C., Altoè, M., \& Bateman, I. J. (2020). CrossCountry Comparisons of Covid-19: Policy, Politics and the Price of Life. Environmental and Resource Economics, 76(4), 525-551. https://doi.org/10.1007/ s10640-020-00466-5
8. Bash, A., \& Alsaifi, K. (2019). Fear from uncertainty: An event study of Khashoggi and stock market returns. Journal of Behavioral and Experimental Finance, 23(October 2018), 54-58. https://doi. org/10.1016/j.jbef.2019.05.004

9. Boehmer, E., Masumeci, J., \& Poulsen, A. B. (1991). Event-study methodology under conditions of event-induced variance. Journal of Financial Economics, 30(2), 253272. https://doi.org/10.1016/0304405X(91)90032-F

10. Brown, S. J., \& Warner, J. B. (1985). Using daily stock returns. The case of event studies. Journal of Financial Economics, 14(1), 3-31. https://doi.org/10.1016/0304405X(85)90042-X

11. Cao, K. H., Li, Q., Liu, Y., \& Woo C. K. (2020). Covid-19's adverse effects on a stock market index. Applied Economics Letters, 00(00), 1-5. https://doi.org/10.1080/13504 851.2020 .1803481

12. Chatterjee, B., Karandikar, R. L., \& Mande, S. C. (2020, October 19). The mortality due to COVID-19 in different nations is associated with the demographic character of nations and the prevalence of autoimmunity. MedRxiv. https:// doi.org/10.1101/2020.07.31.201 65696

13. Chen, C.-D., Chen, C.-C., Tang, W.-W., \& Huang, B.-Y. H. (2009). The Positive and Negative Impacts of the Sars Outbreak: A Case of the Taiwan Industries. The Journal of Developing Areas, 43(1), 281-293. Retrieved from https://www.jstor.org/ stable $/ 40376284$ ? seq=1\#metadata info_tab_contents

14. Chen, M.-P., Lee, C.-C., Lin, Y.H., \& Chen, W.-Y. (2018). Did the S.A.R.S. epidemic weaken the integration of Asian stock markets? Evidence from smooth time-varying cointegration analysis. Economic ResearchEkonomska Istraživanja, 31(1), 908-926. https://doi.org/10.1080/1 331677X.2018.1456354
15. Cucinotta, D., \& Vanelli, M. (2020). WHO declares COVID-19 a pandemic. Acta Biomedica, 91, 157-160. https://doi.org/10.23750/ abm.v91i1.9397

16. David, S. A., Inácio, C. M. C., \& Tenreiro Machado, J. A. (2021). The recovery of global stock markets indices after impacts due to pandemics. Research in International Business and Finance, 55(June 2020). https://doi. org/10.1016/j.ribaf.2020.101335

17. Dutta, A. (2014). Essays on Testing Long-Run Abnormal Stock Returns. In International Business Research (Vol. 7). Retrieved from https://www.univaasa.fi/materiaali/pdf/isbn_978952-476-614-2.pdf

18. Fama, E. F., Fisher, L., Jensen, M. C., \& Roll, R. (1969). The Adjustment of Stock Prices to New Information. International Economic Review, 10(1), 1. https:// doi.org/10.2307/2525569

19. Goodell, J. W. (2020). COVID-19 and finance: Agendas for future research. Finance Research Letters, 35(April). https://doi. org/10.1016/j.frl.2020.101512

20. Hull, R. M., Kwak, S., \& Walker, R. (2018). Hedge fund variables and short-run SEO returns. International Journal of Managerial Finance, 14(3), 322341. https://doi.org/10.1108/IJMF09-2017-0194

21. Izzeldin, M., Muradoğlu, Y. G., Pappas, V., \& Sivaprasad, S. (2021). The impact of Covid-19 on G7 stock markets volatility: Evidence from a ST-HAR model. International Review of Financial Analysis, 74. https://doi. org/10.1016/j.irfa.2021.101671

22. Kilic, E., \& Cankaya, S. (2020). Oil prices and economic activity in BRICS and G7 countries. Central European Journal of Operations Research, 28(4), 1315-1342. https://doi.org/10.1007/s10100019-00647-8

23. Liu, H., Manzoor, A., Wang, C., Zhang, L., \& Manzoor, Z. (2020). The COVID-19 Outbreak and 
Affected Countries Stock Markets Response. International Journal of Environmental Research and Public Health, 17(8), 2800. https://doi. org/10.3390/ijerph17082800

24. Lyócsa, Š., \& Molnár, P. (2020). Stock market oscillations during the corona crash: The role of fear and uncertainty. Finance Research Letters, 36. https://doi. org/10.1016/j.frl.2020.101707

25. Mahmood, M. (2015). The rise of the BRICS and their challenge to the G7. International Journal of Emerging Markets, 10(1), 156170. https://doi.org/10.1108/ IJOEM-07-2012-0063

26. Mishra, A. K., Rath, B. N., \& Dash, A. K. (2020). Does the Indian Financial Market Nosedive because of the COVID-19 Outbreak, in comparison to after Demonetisation and the GST? Emerging Markets Finance and Trade, 56(10), 2162-2180. https://doi.org/10.1080/154049 6X.2020.1785425

27. Mishra, P. K., \& Mishra, S. K. (2020). Corona Pandemic and Stock Market Behaviour: Empirical Insights from Selected Asian Countries. Millennial Asia, 11(3), 341-365. https://doi. org/10.1177/0976399620952354

28. Okorie, D. I., \& Lin, B. (2021). Stock markets and the COVID-19 fractal contagion effects. Finance Research Letters, 38(June), 101640. https://doi.org/10.1016/j. frl.2020.101640

29. Pendell, D. L., \& Cho, C. (2013). Stock Market Reactions to
Contagious Animal Disease Outbreaks: An Event Study in Korean Foot-and-Mouth Disease Outbreaks. Agribusiness, 29(4), n/a-n/a. https://doi.org/10.1002/ agr.21346

30. Shahrokhi, M., Cheng, H., Dandapani, K., Figueiredo, A., Parhizgari, A. M., \& Shachmurove, Y. (2017). The evolution and future of the BRICS: Unbundling politics from economics. Global Finance Journal, 32, 1-15. https:// doi.org/10.1016/j.gfj.2017.03.002

31. Singh, B., Dhall, R., Narang, S., \& Rawat, S. (2020). The Outbreak of COVID-19 and Stock Market Responses: An Event Study and Panel Data Analysis for G-20 Countries. Global Business Review. https://doi. org/10.1177/0972150920957274

32. Singhania, M., \& Saini, N (2018). Determinants of FPI in Developed and Developing Countries. Global Business Review, 19(1), 187-213. https://doi. org/10.1177/0972150917713280

33. Sitthipongpanich. (2011). Understanding the Event Study. Journal of Business Administration, 34(130), 59-68.

34. Song, Q., Liu, J., \& Sriboonchitta, S. (2019). Risk measurement of stock markets in BRICS, G7, and G20: Vine copulas versus factor copulas. Mathematics, 7(3). https://doi.org/10.3390/ math7030274

35. Topcu, M., \& Gulal, O. S. (2020). The impact of COVID-19 on emerging stock markets. Finance
Research Letters, 36, 101691. https://doi.org/10.1016/j. frl.2020.101691

36. Wang, J., Sun, X., \& Li, J. (2020). How do sovereign credit default swap spreads behave under extreme oil price movements? Evidence from G7 and BRICS countries. Finance Research Letters, 34. https://doi.org/10.1016/j. frl.2019.101350

37. Yang, L., Yang, L., \& Hamori, S. (2018). Determinants of dependence structures of sovereign credit default swap spreads between G7 and BRICS countries. International Review of Financial Analysis, 59, 1934. https://doi.org/10.1016/j. irfa.2018.06.001

38. Zaremba, A., Kizys, R., Aharon, D. Y., \& Demir, E. (2020). Infected Markets: Novel Coronavirus, Government Interventions, and Stock Return Volatility around the Globe. Finance Research Letters, 35, 101597. https://doi. org/10.1016/j.frl.2020.101597

39. Zhang, D., Hu, M., \& Ji, Q. (2020) Financial markets under the global pandemic of COVID-19. Finance Research Letters, 36(April), 101528. https://doi.org/10.1016/j. frl.2020.101528

40. Zhang, J., Zhang, D., Wang, J., \& Zhang, Y. (2013). Volatility spillovers between equity and bond markets: Evidence from G7 and BRICS. Romanian Journal of Economic Forecasting, 16(4), 205-217. Retrieved from https:// ideas.repec.org/a/rjr/romjef/ vy2013i4p205-217.html 


\section{APPENDIX A}

The appendix reports an ABHAR table for comparing G-7 and BRICS in an observation window to reflect the continued progressive impact of the event.

Table A1. ABHAR values with t-Stats for G-7 and BRICS except for China for a 90-day window

\begin{tabular}{|c|c|c|c|c|c|c|}
\hline \multirow{2}{*}{$\begin{array}{l}\text { Event } \\
\text { days }\end{array}$} & \multicolumn{2}{|c|}{ G7 } & \multicolumn{2}{|c|}{ BRICS with China } & \multicolumn{2}{|c|}{ BRICS without China } \\
\hline & ABHAR & $T$-stats & ABHAR & $T$-stats & ABHAR & $T$-stats \\
\hline 0 & $-0.16 \%$ & -0.393 & $-0.07 \%$ & -0.147 & $-0.23 \%$ & -0.504 \\
\hline 1 & $-0.60 \%$ & -1.058 & $-1.14 \%$ & -1.798 & $-1.21 \%$ & -1.909 \\
\hline 2 & $-0.80 \%$ & -1.156 & $-1.26 \%$ & -1.621 & $-1.41 \%$ & -1.827 \\
\hline 3 & $-1.46 \%$ & -1.820 & $-2.14 \%$ & -2.391 & $-1.81 \%$ & -2.027 \\
\hline 4 & $-1.16 \%$ & -1.298 & $-3.69 \%$ & -3.688 & $-1.80 \%$ & -1.796 \\
\hline 5 & $-2.91 \%$ & -2.975 & $-5.29 \%$ & -4.829 & $-4.08 \%$ & -3.727 \\
\hline 6 & $-2.26 \%$ & -2.137 & $-4.79 \%$ & -4.049 & $-3.73 \%$ & -3.150 \\
\hline 7 & $-2.02 \%$ & -1.783 & $-4.32 \%$ & -3.414 & $-3.52 \%$ & -2.779 \\
\hline 8 & $-3.40 \%$ & -2.833 & $-4.49 \%$ & -3.349 & $-3.80 \%$ & -2.832 \\
\hline 9 & $-4.24 \%$ & -3.350 & $-5.30 \%$ & -3.745 & $-4.91 \%$ & -3.473 \\
\hline 10 & $-3.86 \%$ & -2.912 & $-5.70 \%$ & -3.843 & $-5.49 \%$ & -3.704 \\
\hline 11 & $-2.66 \%$ & -1.921 & $-4.49 \%$ & -2.898 & $-4.17 \%$ & -2.694 \\
\hline 12 & $-1.81 \%$ & -1.256 & $-4.11 \%$ & -2.550 & $-3.52 \%$ & -2.184 \\
\hline 13 & $-1.13 \%$ & -0.757 & $-4.23 \%$ & -2.529 & $-3.75 \%$ & -2.241 \\
\hline 14 & $-1.36 \%$ & -0.881 & $-4.32 \%$ & -2.493 & $-4.38 \%$ & -2.529 \\
\hline 15 & $-1.49 \%$ & -0.930 & $-4.99 \%$ & -2.791 & $-5.22 \%$ & -2.920 \\
\hline 16 & $-0.90 \%$ & -0.548 & $-4.25 \%$ & -2.306 & $-4.21 \%$ & -2.283 \\
\hline 17 & $-0.55 \%$ & -0.324 & $-3.17 \%$ & -1.670 & $-3.28 \%$ & -1.730 \\
\hline 18 & $-0.86 \%$ & -0.492 & $-3.46 \%$ & -1.774 & $-3.71 \%$ & -1.904 \\
\hline 19 & $-1.20 \%$ & -0.671 & $-3.99 \%$ & -1.993 & $-4.29 \%$ & -2.146 \\
\hline 20 & $-1.13 \%$ & -0.618 & $-3.95 \%$ & -1.926 & $-4.09 \%$ & -1.994 \\
\hline 21 & $-1.29 \%$ & -0.689 & $-4.71 \%$ & -2.246 & $-4.83 \%$ & -2.301 \\
\hline 22 & $-0.93 \%$ & -0.483 & $-3.96 \%$ & -1.845 & $-3.90 \%$ & -1.819 \\
\hline 23 & $-2.15 \%$ & -1.097 & $-5.14 \%$ & -2.348 & $-4.46 \%$ & -2.035 \\
\hline 24 & $-3.76 \%$ & -1.880 & $-5.53 \%$ & -2.471 & $-5.65 \%$ & -2.525 \\
\hline 25 & $-6.73 \%$ & -3.303 & $-8.48 \%$ & -3.718 & $-9.50 \%$ & -4.167 \\
\hline 26 & $-8.78 \%$ & -4.228 & $-8.98 \%$ & -3.866 & $-10.28 \%$ & -4.422 \\
\hline 27 & $-9.46 \%$ & -4.473 & $-9.12 \%$ & -3.856 & $-10.92 \%$ & -4.615 \\
\hline 28 & $-10.93 \%$ & -5.073 & $-11.17 \%$ & -4.637 & $-13.16 \%$ & -5.464 \\
\hline 29 & $-13.15 \%$ & -6.005 & $-13.12 \%$ & -5.358 & $-14.85 \%$ & -6.062 \\
\hline 30 & $-12.85 \%$ & -5.772 & $-11.97 \%$ & -4.809 & $-13.83 \%$ & -5.554 \\
\hline 31 & $-12.51 \%$ & -5.530 & $-12.47 \%$ & -4.928 & $-14.20 \%$ & -5.615 \\
\hline 32 & $-12.73 \%$ & -5.541 & $-13.69 \%$ & -5.328 & $-15.35 \%$ & -5.976 \\
\hline 33 & $-15.62 \%$ & -6.698 & $-17.24 \%$ & -6.610 & $-19.49 \%$ & -7.473 \\
\hline 34 & $-18.37 \%$ & -7.766 & $-19.60 \%$ & -7.407 & $-21.62 \%$ & -8.172 \\
\hline 35 & $-23.39 \%$ & -9.749 & $-22.21 \%$ & -8.276 & $-24.79 \%$ & -9.239 \\
\hline 36 & $-26.38 \%$ & -10.844 & $-27.45 \%$ & -10.092 & $-30.93 \%$ & -11.369 \\
\hline 37 & $-27.97 \%$ & -11.347 & $-25.49 \%$ & -9.247 & $-28.25 \%$ & -10.247 \\
\hline 38 & $-34.75 \%$ & -13.915 & $-30.59 \%$ & -10.953 & $-34.96 \%$ & -12.518 \\
\hline 39 & $-34.34 \%$ & -13.576 & $-31.37 \%$ & -11.091 & $-35.22 \%$ & -12.453 \\
\hline 40 & $-36.91 \%$ & -14.416 & $-35.11 \%$ & -12.262 & $-40.39 \%$ & -14.104 \\
\hline 41 & $-36.86 \%$ & -14.224 & $-33.58 \%$ & -11.587 & $-38.93 \%$ & -13.434 \\
\hline 42 & $-38.43 \%$ & -14.656 & $-33.92 \%$ & -11.566 & $-39.21 \%$ & -13.369 \\
\hline 43 & $-37.64 \%$ & -14.192 & $-37.12 \%$ & -12.515 & $-43.26 \%$ & -14.584 \\
\hline 44 & $-35.55 \%$ & -13.254 & $-34.39 \%$ & -11.464 & $-39.63 \%$ & -13.212 \\
\hline 45 & $-35.96 \%$ & -13.257 & $-33.25 \%$ & -10.963 & $-38.22 \%$ & -12.602 \\
\hline 46 & $-31.39 \%$ & -11.451 & $-31.29 \%$ & -10.204 & $-35.63 \%$ & -11.621 \\
\hline
\end{tabular}


Table A1 (cont.). ABHAR values with t-Stats for G-7 and BRICS except for China for a 90-day window

\begin{tabular}{|c|c|c|c|c|c|c|}
\hline \multirow{2}{*}{$\begin{array}{l}\text { Event } \\
\text { days }\end{array}$} & \multicolumn{2}{|c|}{ G7 } & \multicolumn{2}{|c|}{ BRICS with China } & \multicolumn{2}{|c|}{ BRICS without China } \\
\hline & ABHAR & $T$-stats & ABHAR & $T$-stats & ABHAR & $T$-stats \\
\hline 47 & $-30.64 \%$ & -11.059 & $-31.57 \%$ & -10.190 & $-36.34 \%$ & -11.730 \\
\hline 48 & $-30.38 \%$ & -10.852 & $-31.41 \%$ & -10.034 & $-36.00 \%$ & -11.499 \\
\hline 49 & $-32.51 \%$ & -11.498 & $-31.16 \%$ & -9.853 & $-36.12 \%$ & -11.422 \\
\hline 50 & $-32.56 \%$ & -11.402 & $-32.14 \%$ & -10.063 & $-37.29 \%$ & -11.677 \\
\hline 51 & $-32.37 \%$ & -11.226 & $-31.43 \%$ & -9.745 & $-36.48 \%$ & -11.312 \\
\hline 52 & $-33.55 \%$ & -11.523 & $-31.16 \%$ & -9.572 & $-35.90 \%$ & -11.028 \\
\hline 53 & $-32.55 \%$ & -11.077 & $-29.97 \%$ & -9.120 & $-34.29 \%$ & -10.434 \\
\hline 54 & $-32.48 \%$ & -10.953 & $-28.91 \%$ & -8.717 & $-33.31 \%$ & -10.042 \\
\hline 55 & $-30.57 \%$ & -10.215 & $-28.12 \%$ & -8.401 & $-32.17 \%$ & -9.614 \\
\hline 56 & $-29.26 \%$ & -9.692 & $-27.83 \%$ & -8.242 & $-31.87 \%$ & -9.440 \\
\hline 57 & $-29.64 \%$ & -9.731 & $-27.96 \%$ & -8.209 & $-32.17 \%$ & -9.446 \\
\hline 58 & $-28.29 \%$ & -9.212 & $-27.29 \%$ & -7.944 & $-31.44 \%$ & -9.152 \\
\hline 59 & $-28.49 \%$ & -9.198 & $-27.06 \%$ & -7.813 & $-30.94 \%$ & -8.932 \\
\hline 60 & $-30.55 \%$ & -9.782 & $-29.01 \%$ & -8.306 & $-33.50 \%$ & -9.591 \\
\hline 61 & $-29.93 \%$ & -9.506 & $-28.53 \%$ & -8.101 & $-32.84 \%$ & -9.325 \\
\hline 62 & $-28.87 \%$ & -9.097 & $-28.19 \%$ & -7.943 & $-32.17 \%$ & -9.063 \\
\hline 63 & $-29.36 \%$ & -9.177 & $-28.37 \%$ & -7.931 & $-32.44 \%$ & -9.067 \\
\hline 64 & $-31.13 \%$ & -9.656 & $-29.06 \%$ & -8.060 & $-33.24 \%$ & -9.220 \\
\hline 65 & $-30.07 \%$ & -9.256 & $-28.91 \%$ & -7.958 & $-33.15 \%$ & -9.124 \\
\hline 66 & $-29.70 \%$ & -9.075 & $-27.36 \%$ & -7.476 & $-31.50 \%$ & -8.606 \\
\hline 67 & $-29.70 \%$ & -9.007 & $-26.63 \%$ & -7.220 & $-30.71 \%$ & -8.329 \\
\hline 68 & $-28.66 \%$ & -8.628 & $-27.12 \%$ & -7.301 & $-31.27 \%$ & -8.417 \\
\hline 69 & $-27.41 \%$ & -8.191 & $-27.10 \%$ & -7.243 & $-31.42 \%$ & -8.398 \\
\hline 70 & $-26.56 \%$ & -7.881 & $-27.23 \%$ & -7.225 & $-31.57 \%$ & -8.377 \\
\hline 71 & $-28.40 \%$ & -8.371 & $-27.83 \%$ & -7.334 & $-32.28 \%$ & -8.507 \\
\hline 72 & $-29.74 \%$ & -8.705 & $-28.02 \%$ & -7.333 & $-32.56 \%$ & -8.521 \\
\hline 73 & $-28.77 \%$ & -8.365 & $-27.98 \%$ & -7.274 & $-32.28 \%$ & -8.391 \\
\hline 74 & $-29.09 \%$ & -8.400 & $-27.89 \%$ & -7.203 & $-32.14 \%$ & -8.299 \\
\hline 75 & $-28.70 \%$ & -8.233 & $-27.47 \%$ & -7.045 & $-31.65 \%$ & -8.119 \\
\hline 76 & $-28.29 \%$ & -8.062 & $-28.18 \%$ & -7.182 & $-32.72 \%$ & -8.339 \\
\hline 77 & $-28.43 \%$ & -8.049 & $-28.32 \%$ & -7.169 & $-32.76 \%$ & -8.294 \\
\hline 78 & $-28.39 \%$ & -7.989 & $-29.07 \%$ & -7.314 & $-33.56 \%$ & -8.444 \\
\hline 79 & $-29.63 \%$ & -8.283 & $-30.10 \%$ & -7.525 & $-34.40 \%$ & -8.599 \\
\hline 80 & $-30.62 \%$ & -8.507 & $-29.09 \%$ & -7.228 & $-33.16 \%$ & -8.239 \\
\hline 81 & $-30.44 \%$ & -8.407 & $-27.76 \%$ & -6.854 & $-31.71 \%$ & -7.830 \\
\hline 82 & $-28.28 \%$ & -7.761 & $-27.62 \%$ & -6.779 & $-31.45 \%$ & -7.719 \\
\hline 83 & $-28.48 \%$ & -7.772 & $-26.98 \%$ & -6.583 & $-30.72 \%$ & -7.494 \\
\hline 84 & $-27.51 \%$ & -7.462 & $-27.46 \%$ & -6.661 & $-31.36 \%$ & -7.606 \\
\hline 85 & $-28.14 \%$ & -7.588 & $-26.68 \%$ & -6.434 & $-30.87 \%$ & -7.445 \\
\hline 86 & $-27.77 \%$ & -7.446 & $-26.36 \%$ & -6.320 & $-30.51 \%$ & -7.314 \\
\hline 87 & $-26.77 \%$ & -7.136 & $-25.54 \%$ & -6.087 & $-29.48 \%$ & -7.028 \\
\hline 88 & $-25.94 \%$ & -6.877 & $-25.72 \%$ & -6.096 & $-29.66 \%$ & -7.031 \\
\hline 89 & $-23.29 \%$ & -6.663 & $-25.00 \%$ & -5.892 & $-28.84 \%$ & -6.799 \\
\hline
\end{tabular}




\section{APPENDIX B}

This appendix provides the rationale for choosing BHAR and ABHAR over of CAAR and CAR values in this event study. Figures B1 and B2 show the comparison of ABHAR and CAAR in an observation window. CAAR values capture an additional loss and additional recovery due to its mathematical inaccuracy of adding interest rates similar to simple interest. The approach does not take into account the compounded effect of the market abnormalities, resulting in enhanced miss leading magnitude in capturing the total impact. The rational choice accounts for around 6\% variation in G-7 and 7\% variation in the BRICS nation, which can be misleading. Hence, BHAR and ABHAR are selected over CAR and CAAR in this study.

Source: Authors.

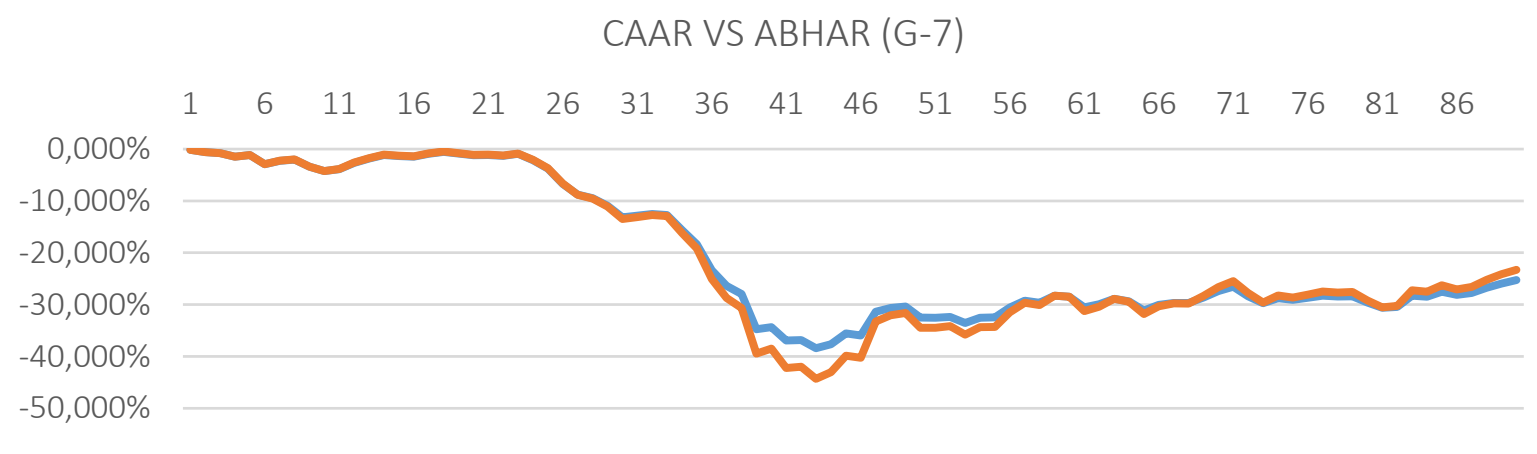

$\longrightarrow$ ABHAR G-7 $\longrightarrow$ CAAR G-7

Figure B1. Choice of ABHAR and CAAR(G-7)

Source: Authors.

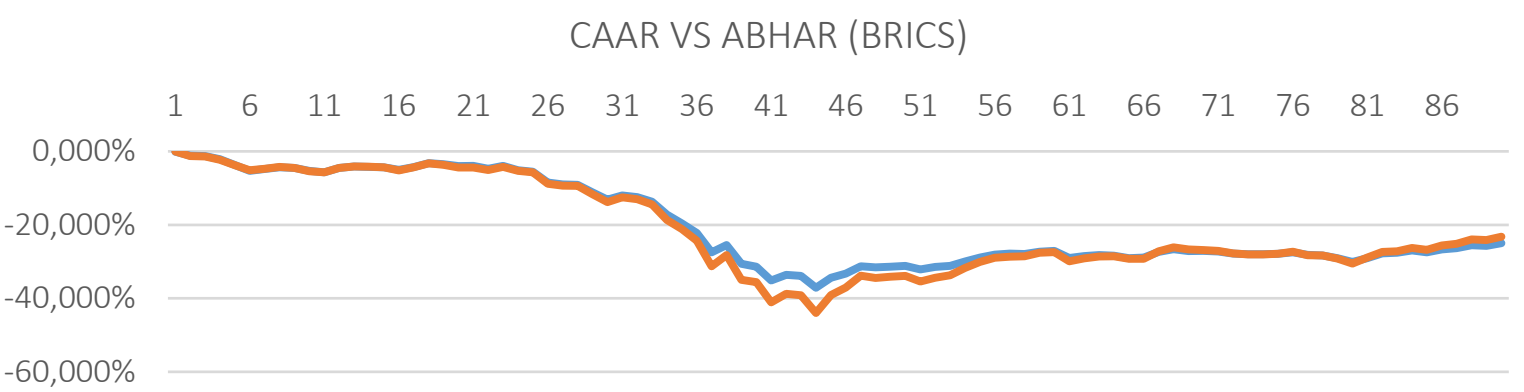

$\longrightarrow$ ABHAR BRICS $\longrightarrow$ CAAR BRICS

Figure B2. Choice of CAAR and ABHAR (BRICS) 